\title{
The Amana Society of Iowa: Two Views
}

\author{
edited by H. Roger Grant*
}

The Amana Society of Iowa was a remarkable utopian experiment. Of all the sectarian communal organizations in America, only the durable Shakers-The United Society of Believers-have a longer history. Residents of A mana or the "Community of True Inspiration" came from a German pietistic background. Immigrating to the United States in the early 1840s, they established a relatively successful communal colony near Buffalo, New York. However, beckoning opportunities and the isolation of the Iowa frontier caused these religious utopians to move to the fertile lands of Iowa County between 1855 and 1865. Here the Amana Society flourished. These thrifty, hard-working Germans continued to operate as a communal enterprise until 1932 when they formed a modern-style corporation. Today descendents of the Amana colonists operate more than thirty enterprises, including a winery and a woolens factory.

Although the historical literature on Amana is extensive, there are few good, contemporary accounts. ${ }^{1}$ Charles Nordhoff, a

*The author wishes to acknowledge his debt to the Faculty Research Committee of The University of Akron for financing his work on the Amana Society. He also wishes to thank Dr. Philip Jordan of Burlington, Iowa, for bringing the report from the Bureau of Labor Statistics to his attention. And he wants to thank Dr. Peter T. Harstad, Director of The State Historical Society of Iowa, for permission to use the B. L. Wick manuscript.

'Useful works on Amana include: Richard T. Ely, "Amana; a Study of Religious Communism," Harper's Monthly Magazine, CV (October, 1902), 659-668; Charles F. Noe, A Brief History of the Amana Society, 1714-1900 (Iowa City: State Historical Society of Iowa, 1904); Grace Chaffee, "Isolated Religious Sect as an Object for Social Research," American Journal of Sociology, XXXV (January, 1930), 618-630; George Schultz-Behrend, "The Amana Colony," American-Ger-

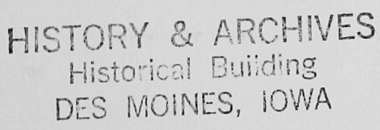


New York City journalist, visited Amana in 1874 and a year later he wrote a marvelous overview of the Iowa utopia in his The Communistic Societies of the United States. ${ }^{2}$ Unfortunately, few first-hand descriptions of Amana equal the Nordhoff work. Yet, there are two obscure pieces, one published in a state report and the other a typed manuscript, that together offer a fine summary of Amana's mature years and its early post-communal days.

The Ninth Biennial Report of the Bureau of Labor Statistics for the State of Iowa, published in Des Moines in 1901, included a fascinating work entitled, "Some of the Economic and Industrial Phases of the Amana Society or the Community of True Inspiration." Its author was Bertha Horak Shambaugh (18711953), wife of the popular Superintendent of the State Historical Society of Iowa. ${ }^{3}$ Mrs. Shambaugh was eminently qualified to write about Amana. "She herself had driven out to the eight oldworld dorfs," recalled Luella M. Wright in the Iowa Journal of History and Politics, "[she] had conversed with the hausfraus and elders, and had taken pictures of the sandstone and the unpainted, vine-clad frame homes and of the Amana women in the plain blue and gray costumes."

While a student at the University of Iowa, Bertha Shambaugh's first study on Amana appeared, an article. "Amana Colony: A Glimpse of the Community of True Inspiration. " in the July 1896 issue of The Midland Monthly. ${ }^{5}$ Later, in 1908, the State Historical Society of Iowa published her book-length manuscript, Amana: The Community of True Inspiration. Then in 1932 the Historical Society brought out Mrs. Shambaugh's revised edition that considered the Amana Society's reorganization. That work,

man Review. VII (December, 1940), 7-9; and William J. Petersen, ed., "Life in the Amana Colony," The Palimpsest, LII (April, 1971), 161-224.

${ }^{2}$ Charles Nordhoff, The Communistic Societies of the United States: From Personal Visit and Observation. . . . (New York: Harper, 1875).

${ }^{3}$ Biographical material on Bertha $\mathrm{H}$. Shambaugh is found in Who's Who in Iowa (Des Moines: Iowa Press Association, 1940), 661.

${ }^{4}$ Luella M. Wright, "The Midland Monthly," Iowa Journal of History and Politics, XLV (January, 1947), 22.

${ }^{5}$ Bertha M. Hoark, "Amana Colony: A Glimpse of the Community of True Inspiration," The Midland Monthly, VI (July, 1896), 27-36. This work was reprinted in the Seventh Biennal Report of the Bureau of Labor Statistics for the State of Iowa, 1895-1896 (Des Moines: F. R. Conaway, State Printer, 1897), $75-81$. 
Amana That Was and Amana That Is, remains the standard source on the Iowa utopia.

It is understandable that the Iowa Bureau of Labor Statistics published Mrs. Shambaugh's description of the Amana Society. Throughout the nation during the populist-progressive era (roughly 1890-1920), scores of reform-minded state officials sought to publicize worker and farmer cooperatives, various innovative industrial plans and even utopian experiments. Perhaps the Iowa Commissioner of Labor believed that residents of the Hawkeye state could learn from the Amana experience.

IN IOWA COUNTY, southeast of the center of Iowa, there is a group of seven villages bound together and surrounded by 26,000 acres of Iowa's richest prairie land. This little garden spot of Iowa is the home of the Amana Society, as it is "known in law," or, as it is called by its members, The Community of True Inspiration.

This community was not founded by a social reformer or by political agitators. ${ }^{\circ}$ It is not an attempt to practice a system of economic theory. But it is rather the outgrowth of a united effort of a small band of German peasants to live honestly according to the promptings of their own consciences.

As a religious organization the community had its beginnings in Southern Germany two centuries ago, ${ }^{7}$ where its members, after the fashion of the age, suffered persecution and exile for the promulgation of their religious doctrines. Naturally they banded together in those troublesome times for mutual comfort and protection. In order that the little band might be fed and clothed it was resolved to rent enough land in common to give profitable occupation to each member of the group. And herein lies the beginning of their communal economic life. The failure of crops, the

\footnotetext{
${ }^{6}$ During the 1890 s virtually all the utopian colonies launched in the United States were founded by social reformers or political agitators. Some sought to implement the tenets of Henry George's "single-tax" theory of land value, while others attempted to build a cooperative paradise free from the control of business "trusts."

'Members of the Amana Society trace their origins to German mystics and pietists of the 16 th and 17 th centuries. As a distinct religious sect the Society dates from 1714 with the writings and teachings of its founders, Eberhard Ludwig Gruber and Johann Friedrich Rock, both residents of Hesse, Germany. However, it was not until nearly the middle of the 19th century that the movement practiced communal living.
} 
heavy rents, and the severity of the government led the leaders of the community to seek a new home in a more promising land to promote their "temporal and spiritual welfare." A committee of four was sent to America, where, after numerous hardships, they selected a spot near Buffalo, New York. Here in 1843, Ebenezer, their first village of a communistic nature, was laid out. ${ }^{8}$ Two more villages were soon established and 800 persons of the faith came from Germany to join the American colony.

After a twelve years' residence in New York, the elders of the Society decided it would be for the best interests of the community to relocate on the frontier where land was cheaper and the opportunities were better for development. ${ }^{9}$ The present location in Iowa County, Iowa, was selected by the committee sent out by the Society; and here they have lived in peace and plenty for half a century. The little handful of Inspirationists in Germany struggling to pay the rent of their first estate has developed into the prosperous Amana Society of today with 1,767 members owning 26,000 acres of land and operating numerous mills and factories whose products find a market from Maine to California.

Thus it will be seen that Amana Society is not a creation; it is a product of gradual development. It has not been elaborated out of Utopian speculations; but it is the result of a long united effort "to live soberly, righteously and godly in the present world."

\section{II}

The permanency and the prosperity of the Amana Society is largely due to its perfect organization. The entire conduct of the affairs of the Society rests with a Board of Trustees consisting of thirteen members who are elected annually by popular vote out of the number of elders in the Community. These trustees elect annually out of their own numbers a President, Vice-President, and a Secretary. All contracts are made by the Board of Trustees, which has, in short, all the rights and privileges of an ordinary corporation. In the month of June in each year the trustees ex-

\footnotetext{
${ }^{8}$ The leading study of the New York-phase of Amana is Frank J. Lankes, The Ebenezer Community of True Inspiration (Garden City, New York: Privately Printed, 1949).

${ }^{9}$ Such an occurrence was not unique in the history of American religious utopias. For example, Dr. William Keil, leader of the Society of Bethel, moved his flock from Missouri to Oregon to take advantage of cheap, western lands.
} 
hibit to the voting members of the Society a full statement of "the real and personal estate of the Society."

It has been the policy of the Society to re-elect from year to year those officers who have satisfactorily fulfilled their duties. The present officers have served nine years.

In each village there are from seven to nineteen elders, who are appointed by the trustees from the older and more spiritually inclined of their members. To the elders of each village is entrusted the management and control of the affairs of that village. It is this group of elders in each village that assigns to each member his apportioned task, his dwelling, etc. And to this group of elders each member desiring more money, more house room, an extra holiday, or easier work, must appeal; for these allotments are as occasion requires "revised and fixed anew."

Every branch of service has its superintendent or "boss" appointed by the elders, and to whom the separate groups of workers are responsible, and who are in turn responsible to the Society.

The system of government is then a sort of federation wherein each village maintains its local independence, but is under the general supervision of a governing central authority, the Board of Trustees.

Each member of the Community "is in duty bound to give his or her personal and real property to the Trustees for the common fund, at the time of his or her acceptance as a member, and before the signing of the constitution. For such payments into the common fund each member is entitled to the credit thereof in the books of the Society and to a receipt signed by the President and Secretary of the Board of Trustees, and is moreover secured for such payments by the pledge of the common property of the Society." These contributions to the common fund of the Society have varied from $\$ 50,000$, the largest sum paid into the treasury by any one member, to the bare working capacity of the ordinary laborer.

Every member is entitled to free board and dwelling, to support and care in old age, sickness, and infirmity and to an annual "sum of maintenance," the amount of which is fixed by the Trustees. "In consideration of the enjoyment of these blessings" the members release all claims for wages, interest, and any share in the income and of the estate of the Society separate from the common stock. 
Members withdrawing from the Society are entitled to receive back the moneys paid by them into the common fund and to interest theron at the rate not exceeding five per cent per annum from the time of the adjustment of their accounts until the repayment of their credits, which rate is to be fixed by the Board of trustees.

Amana Society is first and foremost a religious organization. Its communism is a means for the better development of a spiritual life and "is not practiced for temporal or pecuniary purposes or as an experiment to solve social problems."

Because of the high standard of membership the increase from the outside has been slight during the past quarter of a century in spite of a large number of applications. New members after having given proof of being fully in accord with the religious doctrines of the Society usually have to go through a period of probation. The fact that all religious exercises are conducted in German makes it necessary that those desiring to become members be fully conversant with that language.

The membership of the Society during its residence in Iowa taken by decades is as follows: ${ }^{10}$

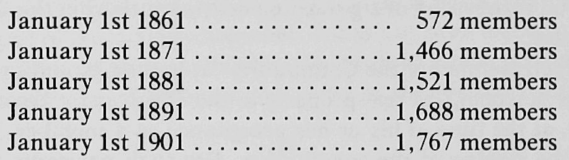

The present population grouped according to ages is as follows:

Number under five years of age ........ 187

Number between ages of five and fifteen ..... 288

Number between ages of fifteen and twenty ... 131

Number between ages of twenty and sixty ... 840

Number over the age of sixty .......... 321

The number of births during the past ten years was 362 ; the

${ }^{10}$ The Twelfth Census of Population of the United States (1900) lists a total population of 1,953 . This number is undoubtedly inflated since the Society employed several hundred non-member laborers. The 1900 manuscript census also provides an ethnic profile of Amana residents: 813 had been born in Germany; 62 in Switzerland; 77 in New York State; 935 in Iowa and the remainder in Bohemia, Austria, Russia and the United States. 
number of deaths 272. Of the number of deaths but one was by accident and two by suicide.

Defectives (the insane, blind, feeble-minded and deaf-mute) are for the most part sent to the state institution for treatment, as there are no special hospitals in the community. The milder cases are, however, cared for in their own homes.

\section{III}

The seven villages of the Society popularly known in Iowa as "The Colonies" are: Amana, the capital and the oldest and largest of the villages; East Amana; Middle Amana; "Amana before the Heights," or High Amana; West Amana; South Amana, and Homestead. The first three villages named have one postoffice in common at Amana. The postoffice for West and South Amana is at South Amana; while High Amana and Homestead have postoffices of their own.

Homestead was a postoffice connected by a stage line with Davenport and Des Moines when the Amana Society first located in Iowa. The railroad was extended through in 1861 , and it was during that year that the embryo town was bought by the Society.

The Chicago, Rock Island \& Pacific Railway passes through Homestead and South Amana. ${ }^{11}$ The Chicago, Milwaukee and St. Paul Railway passes through Amana and High Amana. ${ }^{12}$ The station agents at the several Amana railway stations, and the four postmasters are all members of the Society. All of the colonies are within a radius of six miles from "Old Amana." They are connected with one another, as well as with most of the important towns and cities of the state, by telephone.

The villages are laid out after the manner of the German "dorf," ${ }^{13}$ with one long straggling street and several irregular offshoots. The largest of the seven villages is Amana with ninetyseven houses for its 600 inhabitants. The smallest village is East Amana with thirty-two houses for its 140 inhabitants. Each village has its general store, its school and its church; Amana, Homestead and South Amana have hotels. At the railway stations there are grain houses and lumber yards. The establishment of

\footnotetext{
"This is the mainline of the Rock Island Railroad from Chicago to Omaha.

${ }^{12}$ This is a Milwaukee Road branch from Cedar Rapids to Ottumwa.

13 "Dorf," translated from German, is village.
} 


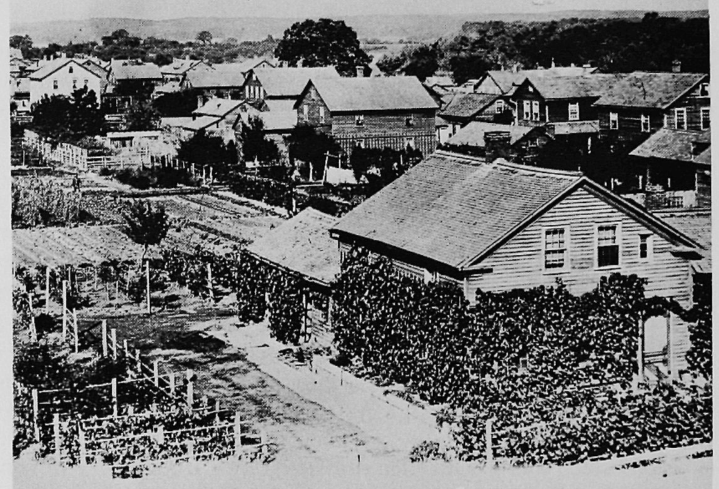

Courtesy Iowa Historical Department, Division of Historical Museum and Archives

A typical scene in the Amana Colonies, circa 1920s.

hotels has been made necessary by the hundreds of strangers who visit the colonies every year. . . . Some come for the outing; for the colonies are delightful places in which to spend one's vacation. Some are interested in political and social science and come for purposes of "investigation" much to the amusement of the colonists. But the greater number come out of sheer curiosity. . . .

The houses are two (sometimes three) story structures of frame, brick or a peculiar brown sandstone that is found in the vicinity. It has been the purpose of the Society to construct the houses as nearly alike as possible-each as desirable as any other. The frame houses are all unpainted, the Society believing it to be more economical to rebuild when occasion requires than to preserve the wood with paint.

The style of architecture is the same throughout the entire community-plain square structures with gable roofs. In the summer time when the houses are uniformily half hidden with vines it is only with the aid of a weather-beaten sign peeping out from a wreath of grape vines or a cluster of roses that the stranger 
is enabled to distinguish the "hotel" or the "store" from the school, the church, or the private dwellings.

Each village has its own saw mill for the working up of hard wood, as the frame houses are for the most part built of hard lumber on the principle that the best material is the cheapest. The lumber used is obtained largely from the Society's own timber land.

The Amana Society does not insure its property against fire. Each village has its water tower and fire engine, and every able bodied man in the village is "ex-officio," a member of the fire department. Although the loss by fire during the last twenty-five years has been between eighty and one hundred thousand dollars, the society still deems it a matter of economy to rebuild rather than pay insurance premiums.

\section{IV}

The land belonging to Amana Society is rich Iowa prairie land at its best. This fact is highly significant, since mutual sympathy and common beliefs without economic prosperity are not abiding bonds of union. ${ }^{14}$ Indeed the perpetuity of such a Society as

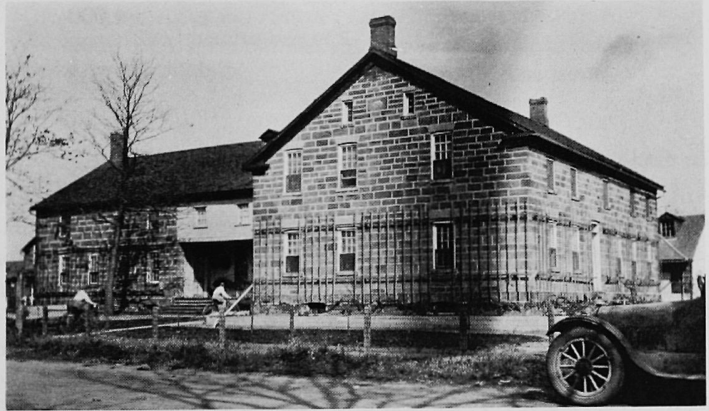

Courtesy Iowa Historical Department. Division of Historical Museum and Archives

One of nine community eating houses in Big Amana, built in 1872. Photograph taken in 1921.

${ }^{14}$ In the annals of American utopianism a common cause for failure was the lack of money. This is especially true for the secular utopian experiments. 
Amana depends ultimately upon the environment of which the soil is the most important factor.

The Iowa river furnishes the water supply for Amana. The water systems of the other villages are supplied by deep wells. The Homestead well is 2,300 feet deep. And in addition to these a canal six feet deep, from thirty to forty feet wide, and seven miles long was dug in the early sixties to conduct water from the river to the mills and factories in the villages to the north. In its course the canal runs through a lake covering about 200 acres, which lies between Amana, the capital, and Middle Amana. The course of the canal is kept clear by a stream dredge which was constructed by the Society several years ago.

Although the Society is still buying land, the manufacturing interests are so great that the Society finds it more profitable to rent some of its land than to devote the extra labor and capital to agriculture.

Exclusive of the rented and swamp lands the 26,000 acres belonging to the Society are divided approximately as follows:

Acres, timberland . . . . . . . . . . 10,000

Acres, cultivated fields . . . . . . . . . 7,000

Acres, grazing land ........... 4,000

Acres, occupied by villages and factories .. 500

Acres, vegetable gardens ........... 100

\section{V}

The general plan of the field work is determined by the Board of Trustees, but a field "boss" or superintendent is responsible to the Society for the proper execution of their orders. He sees that the farm machinery is kept in order, he appeals to the elders for more men to work in the field when necessary, he obtains from the "boss" of the barns and stables the horses needed, etc.

There are from 175 to 200 hired hands, (outsiders and in no way connected with the Society), employed by the Society in the fields every year. Their hours of labor are from 6:30 to 11:00 A.M. and from 12:30 to 6:00 P.M. Their wages are from $\$ 125$ to $\$ 175$ per year, including board, room, heat, etc.

From fifteen to eighteen ox teams are used by the Society for the heavy hauling, it being the experience of the Society that they are better than horses for work which requires heavy and steady pulling. 
The products of agriculture are for the most part wheat, (summer and winter), rye, barley, oats, corn and potatoes. The following was the yield for the year 1900:

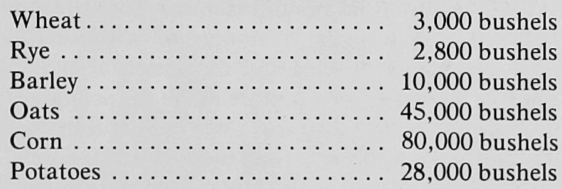

The Society makes no attempt to raise live stock for the market. It buys and sells stock when the market is favorable but aims to have in the end only enough for home consumption. The following is a list of the live stock of the Society for the year 1900:

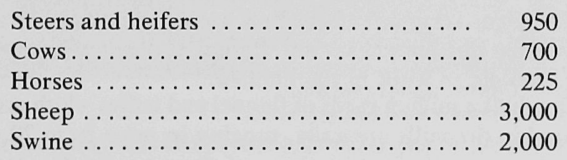

The agricultural products and the dairy products are mostly consumed by the society.

\section{VI}

Amana's mills and factories were among the first erected in the state of Iowa. The two flouring and grist mills, one at Old Amana and the other at West Amana, were important centers half a century ago for the pioneer farmers for fifty miles around. With the exception of one flouring mill in West Amana, which is two miles from the nearest railway, all of the mills and factories are in the villages through which the railroads pass.

The Society is perhaps the best known in the business world through its woolen mills-one in Old Amana and another in Middle Amana-which have been in active operation for forty-two years. Over half a million pounds of raw wool are used in the woolen mills annually. As this is considerably more than the 3,000 sheep belonging to the Society can furnish, a great deal of the raw material is purchased in the outside market. Formerly it was imported from Texas, Colorado and other western states and 
from Australia. Since the imposition of a high tariff is on wool no foreign wool has been used, and at present most of the wool is bought in the Chicago market.

The latest and most improved machinery for woolen manufacturer is found in these mills. A number of inventions along this line have been made by members of the Society. The Society does not patent its inventions, as they are made to facilitate their own work and not for pecuniary gain. The result is that these inventions are copied from time to time by the outside world.

There are about 125 persons employed in the woolen mills. Of this number from sixteen to eighteen are outsiders employed by the Society. Six or eight women (members of the Society) are employed in the woolen mills. This is the only place in industrial Amana, outside of the kitchen and the garden, in which women are employed. Their work in the woolen mills is largely hand work, such as tying threads as they are wound on the large reels. The women thus employed are those who are not strong enough or are too old to work in the kitchen.

One-half a million yards of flannel and ladies' cloth are manufactured in the mills annually, ranging in price from 20 cents to 85 cents per yard. Certain times of the year are devoted to the weaving of blankets, of which 5,000 pairs are made annually, selling at from $\$ 2.75$ to $\$ 7$ per pair. In addition to the above, 15,000 pounds of woolen yarn are made every year, selling on an average at 75 cents a pound. It has always been the aim of the Society to manufacture "honest goods," and they have found a ready market from the Atlantic to the Pacific coast. Ten men, seven of whom are members of the Society, are on the road in the interests of the woolen mills. Some of Amana's customers have bought their woolen goods from the Society every year since 1848 .

The hours of labor in the woolen mills for the greater part of the year are the usual Amana hours of from 7 to 11 A.M.; and from 12:30 to 6 P.M. But during the summer months when the orders for the fall trade are being filled the mills run from half past four in the morning to eleven at night (the factories are lighted throughout by electric light). In spite of the long hours and the busy machinery there is a very unusual factory air about

${ }^{15}$ The "high tariff" is the Dingley Act, which the protectionist McKinley administration pushed through Congress in 1897. 


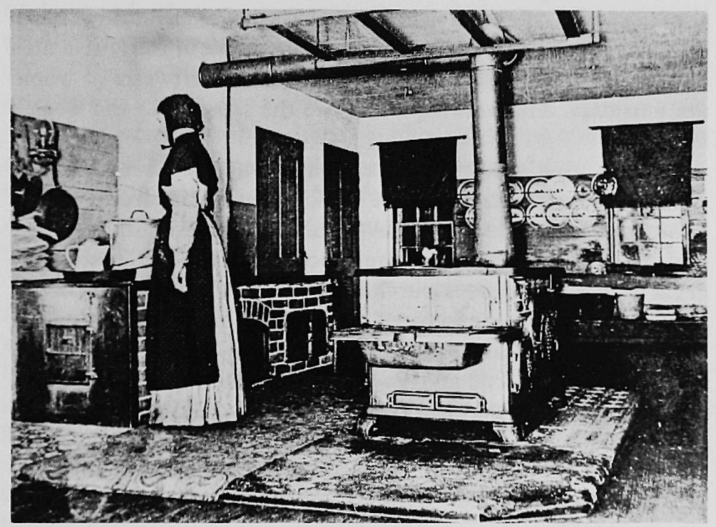

Courtesy Iowa Historical Department. Division of Historical Museum and Archives

A community kitchen in one of the Amana settlements, circa 1910.

the Amana mills. The rooms are light and airy. There is a cushioned chair or stool for every worker "between times." An occasional spray of blossoms on a loom frame reflects the spirit of the workers. Here and there in different parts of the factory is a well equipped cupboard and a lunch table where the different groups of workers eat their luncheon in the middle of each half day. In the villages where the factories are located the boys of thirteen or fourteen years of age who are about to leave school are employed in the mills for a few hours each afternoon "to learn." If the work is congenial they are carefully trained and are given every opportunity to "work up;" but if this employment is not agreeable they are at liberty to choose some other line of work.

In "Old Amana" there is a calico printing establishment. The heavy cotton goods used here are manufactured for the Society in the southern states. Here 4,500 yards of calico are dyed and printed daily. The patterns for the calico are designed and made by a member of the Society. The colors used in the dying are chiefly blue, brown, or black. This "Colony Calico," as it is called, sells at from 7 cents to 10 cents a yard and is sold all over 
the United States and in Canada and is quite as favorably known as the woolen goods. There are from twenty-five to thirty-five men employed in the printing establishment, ten or twelve of whom are outsiders. The working hours are the same as in the woolen mills.

The flouring and grist mills employ about sixteen men, five or six of whom are outsiders. The working hours are from 7 to 12 A.M. and from 1 to 6 P.M. At present a large addition to the flouring mill at Amana is in the process of erection. Most of the grain used in the mills is purchased in the outside market and a large part of the manufactured products is sold to jobbers in this and neighboring states. A few years ago the Society paid a premium on white corn, and in two years time almost the entire yellow corn crop of the vicinity has been replaced with white corn.

The following is a rough estimate of the number of bushels of grain purchased in the market outside of the community and the products manufactured therefrom:

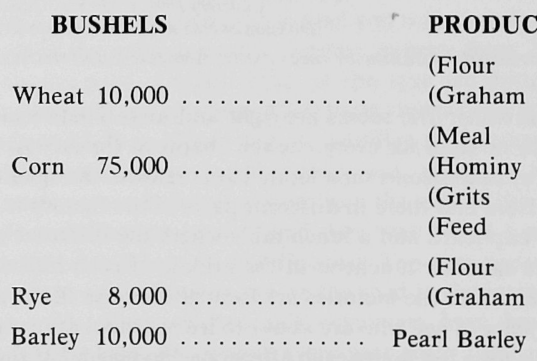

The industrial efficiency of the operatives in the Amana mills and factories is noticeably great to even the casual observer. Each worker labors with the air of a man in physical comfort and peace of mind, and with the energy of a man who is working for himself and expects to enjoy all the fruits of his labor.

Besides the mills and factories already mentioned, the Society owns and operates two machine shops, one at Amana and one at Middle Amana; one soap factory at Amana; and one printing office and book bindery at Middle Amana. The job work for the stores and mills, the text books used in the schools, the hymn 
books used in the churches, and other religious books commonly read in the community are all printed at the Amana printing office. The Society publishes no newspaper or magazine, official or otherwise.

While water was the original motive power used in the mills and factories, it has gradually been supplemented by steam, so that during low water, or when for any other reason the water power furnished by the canal is insufficient, all the milis and factories can be run by steam.

In three of the villages, Amana, Homestead and Middle Amana, there are licensed pharmacies. The quantity of drugs prepared for the outside market is not large, as no effort had ever been made to build up a drug trade. As a rule, only special orders are filled. Many physicians of the state prefer to get their supplies here rather than to send further east for them. The Society were the first people west of Chicago to begin the manufacture of pep$\sin ,{ }^{16}$ and their manufacture is still considered one of the best in the market.

In addition to the aforesaid industries, each village has its shoemaker, tailor, harness-maker, carpenter, blacksmith, toolsmith, wagon-maker, etc. These tradesmen, as a rule, do not devote their entire time to their occupations, but only make and repair what is needed in their line by the people of the village. During the busy season they stand ready to be called to the factory or the field as circumstances demand.

\section{VII}

Each family in the community has its own house. Each member of the family has his own room where he is at liberty to indulge his own taste in decoration, and where he may ride his hobby and store his keepsakes without being disturbed. ${ }^{17}$ There is no crowding anywhere in the colonies. The same spirit that led these people to believe that the purity of the community could better be maintained with more villages and fewer inhabitants in a village has led them to provide plenty of room for their people.

${ }^{10}$ Pepsin, a pharmaceutical, was a powder made from the stomachs of hogs and used chiefly as a digestant.

${ }^{17}$ One reason for the success of the Amana Society was that it did not practice true communism. The Society tolerated private ownership of family keepsakes and other personal property. 
In addition to his livelihood each member of the society is entitled to an annual allowance of $\$ 25$ to $\$ 40$. This allowance is fixed by the trustees "according to justice and equity."

The annual allowance for each member is made in the form of a credit on the books at the store of the village where he or she resides, and all the goods obtained at the store are charged to this account. Each member has a pass-book wherein each debit and credit is entered. At the close of the year these accounts are compared and balanced.

Each woman in the colony makes her own clothes, and each mother makes the clothing for her small children. The village tailor as a rule makes the men's clothing. The dress of both men and women is plain in the extreme. Utility and not adornment is the chief regard. There is nothing characteristic in the dress of the men aside from its severeity [sic]. The dress of the women, however, can never be mistaken for anything but the Amana dress. Fashions never trouble them. The dress of today is the same as it was at the founding of the Society. Mothers and daughters, grandmothers and granddaughters dress alike, not in the sober grays of the Quakers nor in the more brilliant purples of the Amish, but in plain calicoes of gray or blue or brown. The waist is short and very plain; the skirt is long and full. An apron of moderate length, a "shoulder-shawl" and a small black cap completes the summer costume. The only headgear is a sun-bonnet with a long cape. The winter dress differs from this only in being made of flannel; a hood takes the place of the sun-bonnet.

Instrumental music and "worldly amusements" are forbidden by the Society; and so the German's natural artistic sense finds expression in the cultivation of flowers. There are flowers in the front yard, flowers in the back yard, flowers around the hotel and the school house, flowers along the fences and about the hitchingposts. ${ }^{18}$ It is safe to say that nowhere in the state of Iowa are there as many blossoms per square foot in July and August as there are in the Amana villages.

There is no cooking done by individual families in the community. Each village has from four to sixteen large "kitchen-houses"

${ }^{18}$ Elaborate flower gardens were not unique to Amana. For instance, the Zoar Society in Ohio, another German communal experiment, became nationally known for its huge, central formal garden. 
where the meals are prepared and served. The colonists are not faddists in their diet in any respect. Most of their food is raised by themselves and for themselves and is, therefore, of the best. On their tables are found the most delicious butter and cream, good bread and meat, and the choicest of fruits and vegetables. Breakfast is served at 6 o'clock in the summer time and 6:30 in the winter time, dinner at 11:30 o'clock, supper at 6:30 o'clock in the winter time and 7 o'clock in the summer time. Those who work at too great a distance from a kitchen to return for lunch during the middle of the forenoon and afternoon carry their lunches with them. Each kitchen is superintended by one woman, "the kitchen-boss," who is assisted by three of the younger women. These latter take their turn in attending to the dining room, preparing vegetables, cooking, washing dishes, etc. The older women do not cook in the kitchen as a rule; hence it is necessary in some instances to hire help from the outside. The work in the hotel kitchens-exclusive of superintendency-is always done by hired help.

Each village has its bakery, butcher shop, and dairy. Wagons from these places make the daily rounds of the village kitchens.

The Amana Society is very thoughtful and considerate of its women. In every department of service in which women participate the work is carefully apportioned to their strength. Women who have children under the age of three usually take their meals home from the nearest kitchen and are not required to take part in the general village work. During the summer months children between the ages of three and five are cared for at the kindergarten, to enable their mothers to take part in the village work.

In connection with every kitchen house is a vegetable garden of from two to three acres. Each garden is cared for by two or three women. This work is lighter than the kitchen work and the hours are shorter. Hence the garden work is allotted to the middle aged women. In this connection it might be well to repeat that according to the constitution each member of the Society is entitled to "support and care in old age, sickness and infirmity." Unproductive members of the Society enjoy all the privileges and the comforts that the community has to give. It is doubtful whether there are many places in "the world" where more tender care and respectful attention is given the aged and infirm. 


\section{VIII}

The Amana schools are public, not parochia [sic], being supported by the township and sharing in the school fund of the state. Amana township, which the society owns, is divided into independent districts with a school house in each village. They levy their own school tax. build their own school houses, and employ their own teachers. These teachers are all members of the Society and are well educated in both German and English. They attend the County Institute and are examined by the County Superintendent. The wages paid them are $\$ 30$ per month for twelve months; but since they may not keep the money it is turned over to the Society. This amounts then to simply a transfer of figures on the books.

Education in the Amana community is compulsory. Every child must attend school between the ages of five and fourteen. The sessions open early and close late, and there are no vacations. What would otherwise seem like a long tiresome daily session is broken up into three parts: 1 . die Lehr-schule, ${ }^{19}$ when all the common branches are taught; 2. die Spiel-stunde, ${ }^{20}$ or hour of play, when the children romp and play their quaint little German games; and 3. die Arbeits-schule, ${ }^{21}$ or manual training department. In this latter department, during the winter time, the younger boys and girls are taught to knit and crochet. One is surprised to learn how many pairs of stockings and mittens these little folks can make during the year. The older boys usually go during this hour to the different shops and factories for instruction in the trades. The older girls clean up the school house and help in the knitting department. During the summer months, the children keep the school premises in trim-cut the grass, care for the flowers, etc., or help in the garden or the orchards. The atmosphere about the school is more like that of a large household than like that of the ordinary school. The perfect equality maintained has eliminated that shrinking timidity so common among small children. Each child has the air of a stock-holder in the corporation. School discipline, as a care, is reduced to a minimum. When a community of men and women have for generations

19" Die Lehr-schule," translated from German, is learning period.

20"Die Spiel-stunde" is play hour.

${ }_{21}^{21}$ "Die Arbeits-schule" is industrial-training school or program. 
maintained the same high standards of living and of thinking, it is easy to understand why the school children of today are so uniformly well mannered and obedient. There are mischevious boys and giggling girls, but such types as make our city teachers grow old before their time are wholly wanting. No Amana boy or girl has ever been sent to the State Industrial Schools.

The teachers in the school proper are all men, but there are women among the "working teachers." Religious instruction is given, and practical christianity is taught by the parents, and also by teachers to children and young people. The confirmation or reception into the covenant of grace, occurs at the age of fifteen. It is a most solemn act, conducted in open service, when the vow is made in the presence of the whole congregation, as a covenant of faith and with God.

Of the religious life of the community ... [,] suffice it to say that in their business relations as in their private life their aim is to serve God according to His laws and His requirements in their own consciences, and thus to work out the salvation of their souls.

\section{IX}

Although farming and manufacture are not the end of the Society's activity, nevertheless their economic life is most prosperous and successful.

According to the books of the Auditors of Iowa and Johnson counties the assessed valuation of all property owned by the Amana Society in the year 1890 , was $\$ 439,653.00$. This assessment being based on $331 / 3$ per cent of the actual valuation makes the latter $\$ 1,318,959.00$. In 1901 , the total assessed valuation of all Amana property in Iowa and Johnson counties is $\$ 411,155.00$. This valuation is based on 25 per cent of the actual value, hence the actual valuation of Amana property-real and personal-at present, is about $\$ 1,644,620.00$. The increase then in the valuation of the property belonging to the Amana Society in the past ten or eleven years has been something like $\$ 325,671.00$. This increase in valuation is principally due to the advance in the value of land.

The second piece on Amana was written in 1934 by Barthinius L. Wick, (1864-1947), two years after the society broke-up as a communal organizaton. A native of Norway, Wick earned his 
B.A. (1891) and M.A. (1893) degrees from the University of Iowa where he subsequently taught history. Later Wick abandoned academe for the bar; he became a successful lawyer in Cedar Rapids. ${ }^{22}$

Like Bertha Shambaugh, B. L. Wick showed a scholarly interest in the Amana Society. In 1891, Wick, along with William $R$. Perkins, wrote the first serious treatment of the utopia, History of the Amana Society or Community of True Inspiration. ${ }^{23}$ Five years later The Midland Monthly published his article-length study, "Christian Communism in the Mississippi Valley. "24

Although B. L. Wick continued to write a variety of historical books and essays on local history topics, he failed to pursue his early interest in Amana. The following work, now on deposit at the State Historical Society of Iowa, is probably a sketch written for an area newspaper; yet, no record of its having been published can be found. Nevertheless, it contains a vivid, succinct explanation of Amana's demise as a communal religious experiment.

ONE WHO PASSES THROUGH these eight villages cannot fail to stop and reflect and wonder about the economic lessons that are now facing this community.

These families live in houses, some of which have been bought, and others rented, and for the first time in their lives they pay taxes. There is sadness about them because every one feels now that he is relying on himself and he must think of how to get the next meal, and that can't be done on ten cents an hour and ten hours work, even if they have some garden tracts and free doctoring that the corporation grants to the people.

It seems to be nature's protest against a conviction that no matter where one goes or locates, he cannot get away from the world or from onesself [sic].

Dissatisfaction is seen on every hand, except perhaps by those who are on the inside. Those who think and don't say much will at least admit this: that the cause of the failure was that they lost

${ }^{22}$ Biographical material on B. L. Wick is found in Who's Who in Iowa, 762 and the verticle file of the Cedar Rapids Public Library.

${ }^{23} \mathrm{~B}$. L. Wick and W. R. Perkins, History of the Amana Society or Community of True Inspiration (Iowa City: State University of Iowa, 1891).

${ }^{24}$ B. L. Wick, "Christian Communism in the Mississippi Valley," The Midland Monthly, VI (October, 1896), 337-341. 
faith in their religious views as held by the organizers. Another will tell you that civilization and dissatisfaction will creep in everywhere, and no one can escape his fate, and that the world changes have also made drastic changes in the Colony.

The Colony folks will tell you that there has been no rest cure, and no work cure, and the indwelling spirit to guide the little flock has stayed away because they have not sought the Lord closely enough in his dealings with them in the past. We talked to older women, talked to old men, and they began to weep and feel downcast because they feel that there is no assured future for them in conditions as they now exist.

The Society was founded on religion as the basic principle of their faith, and they built their hopes on the supernatural aids and direction like some of the religious bodies of old, in the old countries. The members had been persecuted, and these members had a peculiar affection for one another, and unbounded confidence in their leaders whom they believed to be inspired. . . .

On coming to Iowa there was no persecution. They worked, attended their religious meetings, believed in the inspiration of Christian Metz, ${ }^{25}$ who died in 1867 , and who was perhaps the greatest leader among them who came to America. He was a man of high ideals, religious faith, a preacher among them, a business man, sound and conservative, and with a vision for the better things and the future of the Society. When he spoke they all listened and fell in with his views and his ideas.

The accumulation of wealth has not been their ideal, but they don't live riotously; they always had plenty and the old were cared for.

Gradually the younger ones seemed to lose faith, or there were bickerings, and a feeling that some of them were put down in a place where they believed they should not have been put, and with material power at least; and for the reason, further, that they were not given these offices that they sought.

The younger members began to find fault with one another; they began to lose faith in the inspiration which was the doctrine

${ }^{25}$ Christian Metz (1795-1867) was the Society's foremost spiritual leader in the 19 th century. Members fervently believed that certain pious individuals, like Metz, had the powers of revelation and inspiration. It was, in fact, a divine revelation through Metz that prompted the Society to move to America. 
they had brought from the old country. They lost sight of the frailties of one another, and wanted to change and adopt something else, so that they could be free and equal before the law, and to run and control their own way of thinking, acting and doing.

Strange it is to think that the theory of communism which was so strongly rooted into them, is still believed by many and that if they had complied with the communistic spirit which had been started, their hardships and disruptions would have been over, and the economic condition as now prevailing would not have taken place. Communism, they realized, could only be carried out by leaving the government over to a few, and that the religious phase and financial structure must be based upon two different grounds, and it would not be best to have one control both.

While it is true that this was a communistic society where all were equal, they were not equal as they had to have a central body, and that central body, as far as has been demonstrated, was for the equal benefit of all, and that everyone in the community was provided with a living and with work, according to the best judgment of those in charge of these various offices.

Another thing which brought about the disruption was that the love of obedience and of labor as shown by the older ones gradually became a disintegrating force and the young folks refused to work, saying that as long as they got nothing but their board they refused to do hard work, and every one wanted a job which was easy.

There arose gradually too much individuality among the members, and disolution[sic] of course would come for the reason that when several hundred people work in unison they work differently and cannot get along, and it must be a community founded on temporal progress and equality among all classes, based upon love and the spirit of giving unto others for the benefit of the rest. That there cannot be success in any community where the people are at swords points; but that they must obey, and submit to authority, regardless of self.

The radio, the music box, paved roads, the automobile, the motor cycle, the airplane, the war, [World War I], all upset the way of thinking of these people. Then of course outsiders took the young persons riding and told them they were foolish to live in this way, and then they had a right to be free and equal before the 
law, and that the State and the Government would soon pass laws dissolving the community, and many of them believed that. And many of the youngsters who left the community would come back at stated times and no doubt influenced other younger members to do the same.

But perhaps the main reason being that there was no one big enough to hold the others in tow, or to control them, and the younger element began to form a sort of union within the community, and then the younger element stood up as against the older members, and finally when put to a vote the younger element won out. ${ }^{26}$

There were many things back of this story which have not been made public, but which showed some of the things that had crept in, unconsciously perhaps, but which were there. And then there was a feeling of losing faith in the religious views of their fathers; that they had been misled; that there was no inspiration which was the basic doctrine of their faith; all of which made an impression upon the younger element till they got so unruly that they refused to work, refused to obey orders from their superiors, and refused to comply with the rules of the church, as well as with the regulations of family affairs and the Community.

Finally disruption came about, followed by dissolution of this Communistic Society, which had been held up for seventy years as the ideal Communistic Society in the United States, which had showed from the beginning up to the present an increase in the value of its property, as well as increase in membership.

${ }^{26}$ Iowa's other well-known utopian experiment, The Icarian Society, became famous for its fights between the generations. The colony's young and old split in 1878 and formed separate communities. 
Copyright of Annals of Iowa is the property of State of Iowa, by \& through the State Historical Society of Iowa and its content may not be copied or emailed to multiple sites or posted to a listserv without the copyright holder's express written permission. However, users may print, download, or email articles for individual use. 